doi: 10.52370/TISC2178AS

\title{
THE IMPACT OF COVID-19 ON WORLD TOURISM
}

\author{
Aneta Stojanovska-Stefanova ${ }^{1}$; Marija Magdinceva-Sopova ${ }^{2}$
}

\begin{abstract}
The article presents the effects of Covid-19 world tourism in 2020. The goal of the paper is to research the consequences of the pandemic on the tourism sector. The paper presents and reviews the available information on how tourism was affected by the pandemic, endangered jobs, and ways in which countries are dealing with the consequences. The paper discusses possible measures and scenarios of the countries to mitigate the effects of the crisis and accelerate the recovery of tourism and the economy. Summarizing the findings, authors will conclude that the disruption in tourism from the pandemic had a huge impact on the wider economy, and countries' governments reacted quickly. The scope of imposed measures expanded continuously during the crisis. At the end, recommendations are given for the priorities for renewal of tourism and protection of jobs, as recommendations for solidarity and promotion of mutual cooperation.
\end{abstract}

Key Words: tourism, travel, countries, pandemic, policy, recovery JEL classification: Z32, L83, I15

\section{Introduction}

The coronavirus showed the power to paralyze the societies and their economies on a global level. This pandemic hit world tourism hard and left deep consequences as well. As UNCATD points out, the world economy was strongly hurt with serious damages that throw a shadow on all individuals and communities worldwide. The weak and defenseless countries were the ones that were hit the most as a result of the quick spread

\footnotetext{
1 Aneta Stojanovska-Stefanova, Assistant Professor, Goce Delcev University - Stip, Faculty of Tourism and Business Logistics, Str.7mi Noemvri b.b. Gevgelija, North Macedonia, aneta.stojanovska@ugd.edu.mk

${ }^{2}$ Marija Magdinceva-Sopova, Associate Professor, Goce Delcev University - Stip, Faculty of Tourism and Business Logistics, Str.7mi Noemvri b.b. Gevgelija, North Macedonia, marija.magdinceva@ugd.edu.mk
} 
of the virus across the countries and the world's economy that has led to an enormous crisis worldwide. (UNCTAD, 2020).

The Secretary-General of UNCTAD Mukhisa Kituyi - shared the hope that this "better healing" could sow the seeds of a wholesome, equitable and greener globalization that can be nurtured by a stronger approach to multilateralism. By and large, the most common measures adopted by the states are packages to stimulate the economy as a whole, mostly aimed at the most affected sectors (UNCTAD, 2020). Undoubtedly, tourism is one of the most directly affected. "Fiscal stimulus packages mostly refer to VAT exemptions or delays as well as profit tax, emergency economic funds and economic assistance especially SMEs, the self-employed and investment programs aimed at mitigating the effects of the pandemic" (UNWTO, 2020a).

According to UNWTO Policy Brief from June 2020, there is a strong and widespread political response to the action caused by the Covid-19 pandemic in the regions. From 220 countries and territories analyzed in 2020, a total of 167 countries have reported on specific measures aimed at reducing the crisis effect and accelerating the recovery process. More than 144 countries among them, have adopted fiscal and monetary policy, along with policies to support jobs and training that have been conducted by 100 countries (UNWTO, 2020a). We must say that fiscal and monetary policy is one of the most widespread in the regions.

The disruption that occurred in tourism has a cause-and-effect impact on the economy as a whole, given the interconnectedness of the sector. The OECD estimates that more than a third of all domestic tourism value added comes from indirect impacts, which reflect the magnitude of links between tourism and other sectors (e.g. food production, agriculture, transport, business services). One of the most affected sectors of the Covid-19 pandemic is undoubtedly tourism, and it affects economies, livelihoods, public services, and so on. Maintaining a sector-dependent livelihood must be a priority, but the renewal of tourism is "also an opportunity for change with a focus on supporting its impact on tourist destinations and building stronger communities and businesses through innovation, sustainability, digitalization and partnerships" (UN, 2020).

According to United Nations, the number of international tourists has decreased significantly due to travel restrictions as well as falling consumer demand. All this has led to economic deficits and job losses. The greatest 
risk of losing jobs in tourism such as closing businesses due to the pandemic undoubtedly exists among women, young people and everyone working in the informal economy (UN, 2020a). In addition, the hardest hit will be destinations and jobs that are directly related to tourism. Hence, the purpose of this paper is to research how the Covid-19 pandemic affected world tourism and how tourism disruption affected the economies of countries, tourism sector and the jobs, as well as how the governments of the countries dealt with pandemic and the effects on the tourism. This paper will also develop a discussion of possible future measures and scenarios for assistance and healing of tourism and the economy worldwide. The paper suggests that a dialogue between the tourism sector and the governments could be beneficial in order to share knowledge and define consequences affecting the tourism industry, as well as to find the best applicable measures in the future.

\section{Literature review}

Tourism is an important source of employment for many developing countries, it also represents a good way for country promotion (Stojanovska-Stefanova \& Atanasoski, 2017). The pandemic caused by Covid-19 will directly affect tourism and the road sector (Strielkowski, 2020). The vulnerability of the tourism and hospitality industries has come to the fore due to travel restrictions and advice. (De Sausmarez, 2004; Kaushal \& Srivastava, 2020; Zhang et al., 2020). The virus affected virtually all parts of the world as well as every segment of tourism industry. The travel measures as well as social distance recommendations make an impact on accommodations, the events were cancelled worldwide and the restaurants had to close. In some countries, "a modification of the restaurants to take-away delivery sales allowed some to continue operations" (Gössling et al., 2021).

The unprecedented effect of the coronavirus pandemic was felt in the hotel industry and that has confronted social and economic risks, cancelled arrangements and events (Mehta et al., 2021). Coronavirus disease has rapidly affected our day-to-day life and the global economy too. The damage of "such event re-emphasizes the vulnerability of tourism industry" (Jiang \& Ritchie, 2017). Therefore, "the health care quality innovation will have an important role in fighting this pandemic crisis" (Zsifkovits et al., 2016). 
Some authors explore "the relationships between tourism and sustainable development through the lens of the Covid-19 crisis" (Leal-Filho, 2020; Jones \& Comfort, 2020; Daphne, 2020). Other researches (Mistilis \& Sheldon, 2006) "focus on the need for the destinations to create a knowledge-based system to assist with crisis and disaster management". Also, some authors emphasize "the vulnerability of tourism in the face of disasters and the challenges of establishing recovery" (Yeh, 2020). The rapid changes in the environment impose the need to apply innovative tools in all segments of the business. Innovative enterprises are characterized by the ability to make the most of new job opportunities, innovations, scientific breakthroughs, the use of modern technology in work and new approaches to employees, (Magdinceva Sopova, et al, 2018). Effective enterprise management means formulating a proper business strategy, therefore human resource planning is a necessary management activity in any enterprise (Magdinceva Sopova et al, 2017).

There is no doubt, that the "impact of Covid-19 on the travel tourism industry will be incomparable to the consequence of the previous pandemic episodes" (Škare et al., 2021). For very short period, "the global tourism system moved from over-tourism" (Dodds \& Butler, 2019; Seraphin et al., 2018) "to non-tourism, vividly illustrated by 'before' and 'after' photographs in social media news" (Condé Nast Traveller, 2020). "Demographic patterns in Europe and the rest of the world make population more vulnerable to future epidemic outbreaks" (Skirbekk et al., 2015). "The impact of pandemic is significant and requires an interdisciplinary research tackle" (Wen et al., 2020). "Government plays a major role in the fight against the Covid-19 on many levels, such as the recovery of the economy, which includes tourism industry" (Shih-Shuo, 2020).

\section{Methodology}

The main hypothesis of the authors for writing this paper is that "the Covid19 pandemic hit world tourism hard and left deep consequences." Auxiliary hypotheses are that "the Covid-19 pandemic has endangered the jobs of tourism industry employees", "the Covid-19 pandemic has profound economic effects on the countries" and "flexible policy solutions are needed to build more sustainable and resilient tourism economy in the future". The authors will try to prove the basic and auxiliary hypothesis through a process of analysis and synthesis, generalization and specialization, induction and deduction, abstraction and concretization, as well as through all concepts and forms of thinking. 
The hypotheses are tested and discussed by the authors through the available data, analysis of the knowledge of international organizations (particularly the OECD, the United Nations and its specialized agencies) where the countries as member states are most called to deal with the pandemic. The hypotheses are tested and discussed by the authors through available scientific sources that deal with the topic and large numbers of academic papers published in prestigious journals, as well as through the method of direct monitoring of the demonstrated behavior of the states in dealing with the pandemic and creating measures for dealing with the economic and health crisis.

\section{Countries' losses due to Covid-19 crisis and proposed measures for tourism recovery}

International tourist arrivals reached 1.5 billion in 2019 , which is a growth of 4 percent compared to 2018, which strengthened the ten-year record where tourism had faster growth than the world economy as a whole. New 8.8 billion tourist arrivals were added by domestic tourism. The sector earned $\$ 1.5$ trillion from exports and directly or indirectly employed one in ten people (UNWTO, 2020a).

In mid-March 2020, tourism came to a halt. The first months of this year compared to last year show that international tourist arrivals decreased by 56 percent with data for May which decreased by 98 percent. All of this is an export loss of almost $\$ 320$ billion, which is actually three times more than the losses during the global economic crisis in 2009.

Advanced scenarios suggest that there may be reductions in arrivals and revenues from tourism internationally, i.e. 58 percent to 78 percent for the whole year, depending on how long the pandemic lasts, travel restrictions and the opening of borders that have just begun, but all this remains uncertain. This huge shock could translate into numbers or a drop in tourism from 850 million to 1.1 billion and a loss of tourism export revenue of $\$ 910$ billion to $\$ 1.2$ trillion that could put 100 to 120 million tourism jobs at risk.

In some parts of the world, travel is starting again, and with it, the limited connectivity, as well as the weak consumer confidence but also the unknown development of the pandemic and the impact of the economic downturn, are new challenges for the tourism sector. Key to accelerating the recovery of the economy is of course supporting households that are 
dependent on "a sector affected by months of inactivity, and building a sustainable and responsible travel experience that is safe for communities, workers and travelers" (UN, 2020). Tourism is right in front of the crossroads and all the measures that will be adopted today will form what tourism will be tomorrow. The long-term effects of the crisis need to be taken into account by governments as well as benefiting from "digitalization and supporting the low carbon transition and supporting the structural transformation needed to build a stronger, more sustainable and stronger tourism economy" (OECD, 2020).

Figure 1: Receipts from international tourism (exports) 2000-2019 and 2020 scenarios

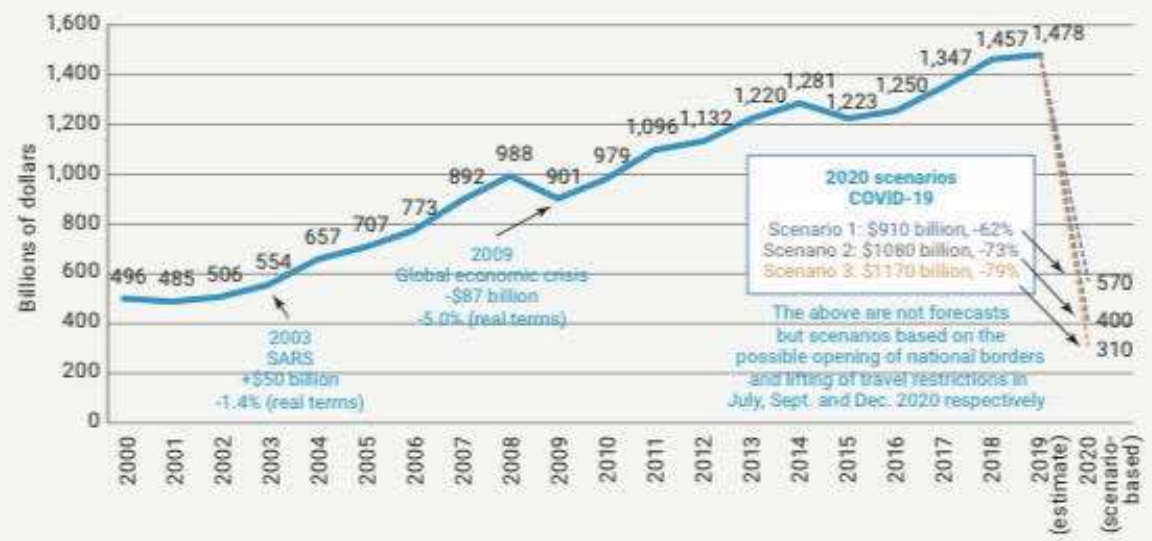

Source: United Nations, 2020

According to UNWTO (2020b) some countries have already approved financial support for their state-owned airlines, including Finland, Italy and New Zealand, while Brazil, Costa Rica and Norway have announced air travel and other aviation tax delays. In the Russian Federation, travel companies and airlines will have the right to defer their tax payments. Guatemala has approved a deferral of taxes on accommodation and airline tickets. Singapore has also reduced airport fares.

The same report states that Bulgaria's government will assist businesses (catering, travel agencies and tour operators, restaurants and fast-food establishments), and will cover insurance payments owed by employers. Serbia, Slovenia and Slovakia have announced they will make direct payments to companies (or a percentage of salaries) that have been forced to close due to the pandemic. 
In North Macedonia the Government also adopted five set economic measures packages aimed at reducing the impact of the coronavirus outbreak by supporting both citizens and the economy. These measures are in order to provide help for the sectors which are most affected by the coronavirus outbreak such as companies operating in tourism, transport and hospitality. The measures foresee subsidizing up to $50 \%$ of the social contributions due for North Macedonia's average salary in 2019, interestfree loans, as direct assistance to micro, small and medium-sized enterprises, distribution of vouchers for summer holidays in tourist regions in the country for the citizens with low income etc. (WHO, 2021). Montenegro aimed salary grants for May and April 2020 for the tourism sector. The government in Spain provide measures to support the extension of workers' periods of "permanent employment in the tourism and trade and hospitality-related sectors of the tourism sector" (UNWTO, 2020).

Moreover, "Sweden eased short-term layoffs: employers' wage costs can be halved with the central government covering a larger share of the costs" (UNWTO, 2020). According to UNWTO (2020), workers whose employment contracts have been temporarily canceled will receive compensation and the state will cover the costs of social and health insurance in Greece. Similar relief or assistance from countries in terms of social security contributions has been observed in other countries and territories, ie in Argentina, Kuwait, Morocco, Mongolia, New Caledonia, Samoa and Hungary where the payment of contributions by employers has been stopped in and the state will take over $70 \%$ of the lost wages in three months in support of part-time workers. Similar measures have been adopted by the following countries: Brunei, China, Fiji, Malaysia, New Zealand, Papua New Guinea, Senegal, Singapore and Vanuatu. The Federal Government Center of Excellence for Tourism in Germany established a corona-navigator website that is used to keep up to date with the latest news, facts and recommendations and to provide guidance to all shareholders (UNWTO, 2020).

The OECD Policy Responses to Coronavirus (Covid-19): "Rebuilding tourism for the future: Covid-19 policy responses and recovery" provides analyses for the tourism in 2020 in Canada, Croatia, German, Switzerland, and United Kingdom. Domestic tourism is expected to recover to the levels in 2019 only in the summer of 2021, with forecasts for international tourism to recover sometime in April 2023 (ie two years longer). Annual turnover is expected to decrease compared to 2019 by: "42\% in domestic and 57\% 
in international tourism in 2020, $14 \%$ in domestic and 52\% in international tourism in 2021 and 30\% in international tourism in 2022" (OECD, 2021).

According to the Swiss Institute of Economics (COF), the number of overnight stays in Switzerland is projected to fall by $34 \%$ in 2020 , the OECD said. The decline in domestic demand is projected to be relatively small (decline of 14\%), and the loss in international business is significant (decline of 55\%). "Domestic and European demand is expected to recover steadily, but demand from overseas markets is not expected to recover until 2023" (OECD, 2021).

Also, as a result of the tourism crisis, UNCTAD, estimates that global GDP losses could amount to $2.8 \%$ of world GDP (\$ 1.2 trillion) if international tourist arrivals fall by $66 \%$, with the most significant consequences for countries such as Croatia (potential GDP decline of 8\%), Portugal (6\%), Morocco (4\%), Greece (4\%), Ireland (3\%) and Spain (3\%). This could rise to a $4.2 \%$ drop in world GDP ( $\$ 3.3$ trillion) if international tourism flows are dormant for 12 months (UNCTAD, 2020).

According to the conclusion of the United Nations (2020d), the roadmap for tourism transformation should include five priority areas that will manage the crisis but also reduce socio-economic impacts with special emphasis on employment and women's economic security, further to increase market competitiveness as well as to promote the innovation of the entire tourism ecosystem, foster sustainability as well as a partnership to change tourism and achieve SDG's.

Government support needs to be directed towards building a more sustainable and resilient tourism economy. When the recovery from the pandemic begins, tourism should be ready to provide services in order to meet demand. It will be necessary to work with tourism businesses to continue to be sustainable after the end of support and to address the longterm consequences of the crisis. Millions of tourism jobs are at risk due to the crisis and pandemic. Tourism provides a number of jobs for low-skilled workers, along with higher-skilled jobs.

The most vulnerable as a result of the impact on tourism from Covid-19 are women and they cover $54 \%$ of the total workforce in the tourism sector, $32 \%$ are young, migrants who have limited or no access to social protection according to the International Labor Organization (ILO, 2020a). 
Figure 2: Employment in the most affected sectors, 2018

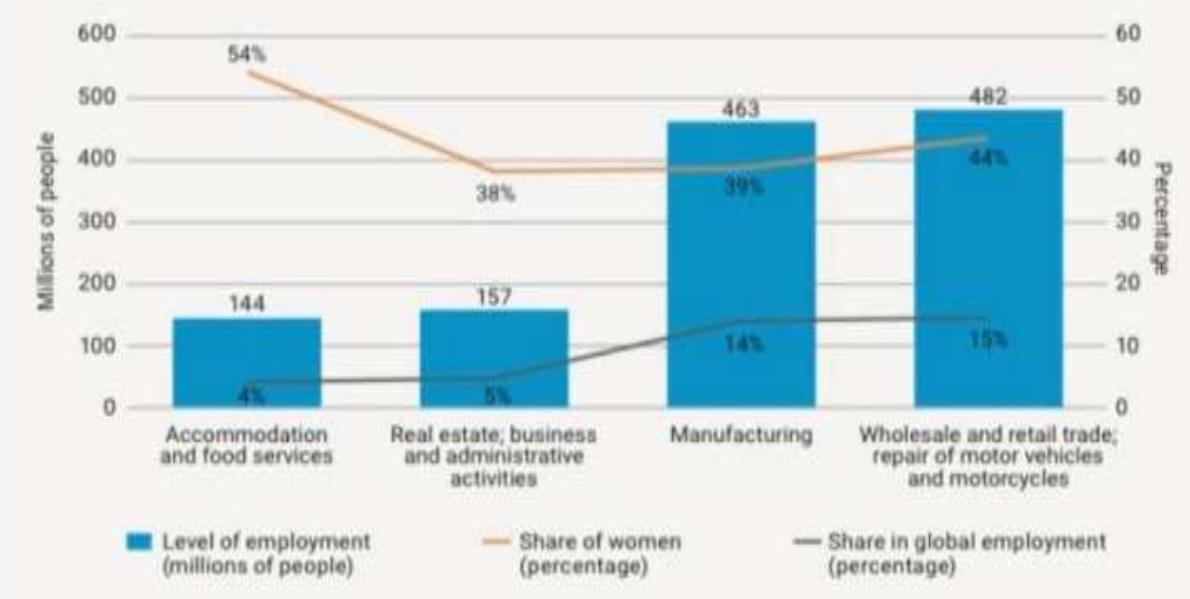

Source: UNWTO (2020d)

The OECD in 2020 announced that the governments have taken impressive action to "cushion the blow to tourism", to minimize consequences as the employment losses and to build recovery in 2021. Since the pandemic is easily "passing the borders" multilateral approaches of finding policy solutions are necessity for the future. Among the priorities of the countries, according to OECD (2020) are to restore and strengthen the cooperation within and between countries, to improve traveler confidence and to support tourism sector, so it may adapt and survive. Also, key priorities are to promote domestic tourism and to support safe return of international tourism and to build more resilient and sustainable tourism.

\section{The main challenge: How to recover tourism after the Covid-19 pandemic?}

In order for the tourism economy to keep pace with the virus in the short and long term, adaptable solutions are needed. It is very important to learn from the whole crisis, especially as there have been gaps in government and industrial capacity in terms of power to cope and respond appropriately to the crisis. Covid-19 threatens the long-term well-being of millions of people in addition to the threat to health and socio-economic disruption (ILO, 2020c). Worldwide, 144 million workers are employed in housing and food service jobs. This includes approximately 44 million selfemployed workers and 7 million employers (UNWTO, 2020d; ILO, 2020b). Women's incomes are particularly affected by measures to close 
markets for handicrafts, products and other goods. The goal of recovery and response to the Covid-19 pandemic must be to ensure the involvement of 476 million people worldwide, said UN Secretary-General António Guterres has underscored (UNWTO, 2020c).

The Covid-19 pandemic is a kind of opportunity to analyze the tourism sector and its contribution to SDGs as well as the Paris Agreement on climate change. The whole crisis is an opportunity to work towards a more sustainable, inclusive and sustainable. Tourism has the potential to contribute, directly or indirectly, to all of the SDGs. "In particular, it has been included as targets in SD Goals 8, 12 and 14 on inclusive and sustainable economic growth, sustainable consumption and production (SCP) and the sustainable use of oceans and marine resources, respectively" (Stojanovska-Stefanova et al., 2019).

In the 2030 Agenda, sustainable tourism is positioned very firmly. "Only through collective action and international cooperation will we be able to transform tourism, advance its contribution to the 2030 Agenda and its shift towards an inclusive and carbon neutral sector that harnesses innovation and digitalization, embraces local values and communities and creates decent job opportunities for all, leaving no one behind" (UNWTO, 2020d).

Looking for new opportunities in the recovery phase UNWTO and Google have strengthened their partnership to promote digital skills. The UNWTO (2020d) underlines that in response to the crisis, the governments need to focus on the impact of the tourism sector on its domestic conditions as well as employment worldwide. In addition, care must be taken to protect employees and to make the necessary efforts to activate the positions they hold. All these solutions and responsibilities should be faced with a gradual and highly practical way to protect the revenues and the companies themselves. Furthermore, it is also very possible to build trust in all tourism activities through all the protocols necessary for health safety. Because of the solutions that are needed, competitiveness should be linked and strengthened to build resilience. It is also necessary to help the innovations and the overall digitalization of the tourist ecosystem. Sustainable and inclusive green growth as well as strengthening coordination and partnerships are needed to change tourism and achieve UN SDGs. This crisis is possible so that it (tourism) can be transformed and sustained due to the impact of Covid-19 on tourism and to protect millions of livelihoods. The OECD (2020) underlined that "crisis is a great opportunity to move 
toward reasonable, more sustainable and resilient models of tourism development".

\section{Conclusion}

The Covid-19 crisis hit hard and left a mark on one of the most dynamic and intense sectors today. Tourism is the reason for the livelihoods of millions of people around the world and a reason too for billions of people to appreciate and respect both their own and different cultures and the natural world too.

Tourism in some countries represents even over $20 \%$ of total GDP and in general, and tourism is the third largest export sector of the world economy. Travel and tourism are among the most affected sectors, as the world is facing tremendous Covid-19 pandemic.

Data from the UN World Tourism Organization (UNWTO) shows that 100 to 120 million direct tourism jobs are at risk. The UN Conference on Trade and Development (UNCTAD) forecasts a loss of 1.5 to 2.8 per cent of global GDP (UN, 2020c). Therefore, tourism was in the main focus of the governments, international organizations as well as scholars in this field.

According to the available data from the international organizations, the most of the measures adopted by the states aim to provide financial support to SMEs, as well as to self-employed workers and to promote the job retention and secure employment.

The countries around the world have implemented travel restrictions to prevent the spread of the virus. We may conclude that the disruption in tourism from the pandemic had a huge impact on the wider economy, and countries' governments reacted quickly and strongly to provide best possible relief. Most of the countries have implemented stimulus packages and support measures for the employees. The scope of imposed measures expanded continuously during the crisis.

Tourism is one of the hardest hit sectors with a wide range of consequences, therefore it is at the center of such policies. The states have implemented special measures that are aimed directly on tourism, especially in those countries where tourism sector contributes greatly to the national economy. Therefore, the authors have confirmed the hypothesis frame set at the beginning of the paper that the Covid-19 pandemic hit world tourism hard 
and left deep consequences. The Covid-19 pandemic has endangered the jobs of tourism industry employees, and the pandemic has profound economic effects on the countries, therefore new flexible policy solutions are needed in order to build a more sustainable and resilient tourism industry in the future.

Many countries are also now developing measures to build a more resilient tourism economy post COVID-19. These include preparing plans to support the sustainable recovery of tourism, promoting the digital transition and move to a greener tourism system, and rethinking tourism for the future (OECD,2020).

Among the measures recommended by United Nations (2020b, 2020c) and OECD (2020) are that the countries have to protect jobs, as well as to implement new technologies. To mitigate the effects of the crisis and accelerate the recovery of tourism and the economy, the international organizations generally recommend the states to open their borders with responsibility, to implement safety and security protocols, to improve travelers' confidence and to focus on innovation and sustainability as the new normal in the near future.

\section{References}

1. Condé Nast Traveller, (2020), Before and after: How coronavirus has emptied tourist attractions around the world, https://www.cntravellerme. com/before-and-after-photos-tourist-attractions-during-coronavirus, March 2020).

2. De Sausmarez, N. (2004). Malaysia's response to the Asian financial crisis: implications for tourism and sectoral crisis management. Journal of Travel \& Tourism Marketing, Vol. 15, No. 4, 217-231.

3. Dodds, R., Butler, R. W. (2019). Overtourism. Issues, realities and solutions, Walter de Gruyter GmbH, Berlin/Boston.

4. Gössling, S., Scott, D., Hall, C. M. (2021). Pandemics, tourism and global change: a rapid assessment of COVID-19. Journal of Sustainable Tourism, Vol. 29, No. 1, 1-20.

5. International Labour Organization - ILO, (2020), "COVID-19 crisis and the informal economy: Immediate responses and policy challenges", 5 May 
2020, available at https://www.ilo.org/global/topics/employmentpromotion/informal-economy/publications/WCMS_743623/lang-en/index.htm, (02 March 2021).

6. International Labour Organization - ILO, (2020a), "COVID-19 and the tourism sector", available at https://www.ilo.org/sector/Resources/ publications/WCMS_741468/lang--en/index.htm, (02 March 2021).

7. International Labour Organization - ILO, (2020b), "ILO Monitor: COVID-19 and the world of work", Fifth edition, available at https://www.ilo.org/wcmsp5/groups/public/@dgreports/@dcomm/docum ents/briefingnote/wcms_749399.pdf, (04 March 2021).

8. International Labour Organization - ILO, (2020c), "ILO Monitor: Covod-19 and the world of work", available at https://www.ilo.org/global/ topics/coronavirus/lang--en/index.htm, (02 March 2021).

9. Jiang, Y., Ritchie, B. W. (2017). Disaster collaboration in tourism: Motives, impediments and success factors. Journal of Hospitality and Tourism Management, Vol. 31, 70-82.

10. Jones, P., Comfort, D. (2020). The COVID-19 Crisis, Tourism and Sustainable Development. Athens Journal of Tourism, Vol. 7, No. 2,75-86.

11. Kaushal, V., Srivastava, S. (2021). Hospitality and tourism industry amid COVID-19 pandemic: Perspectives on challenges and learnings from India. International Journal of Hospitality Management, Vol. 92, 102707.

12. Leal-Filho, W., Azul, A. M., Wall, T., Vasconcelos, C. R., Salvia, A. L., do Paço, A., Frankenberger, F. (2021). COVID-19: the impact of a global crisis on sustainable development research. Sustainability science, Vol. 16, No. 1, 85-99.

13. Magdinceva-Sopova, M., Bardarova, S., Stojanovska-Stefanova, A. (2017). The role of the entrepreneur in managing the professional stress of the employees. First International Scientific Conference Challenges of tourism and business logistics in the 21st century »ISCTBL 2017«. Gevgelija/Shtip, 1, 286-298.

14. Magdinceva-Sopova, M., Stojanovska-Stefanova, A., Dimitrov, N., Josheski, D., Elenov, R. (2018). Innovative management concept as 
possibility for development of tourism in the Republic of Macedonia. International Journal Knowledge, Vol. 26, No. 1, 83-89.

15. Mehta, M. P., Kumar, G., Ramkumar, M. (2021). Customer expectations in the hotel industry during the COVID-19 pandemic: a global perspective using sentiment analysis. Tourism Recreation Research.

16. Mistilis, N., Sheldon, P. (2006). Knowledge management for tourism crises and disasters. Tourism Review International, Vol. 10, No. 1-2, 3946.

17. Organisation for Economic Co-operation and Development - OECD, (2019), Policy Responses to Coronavirus (COVID-19), Rebuilding tourism for the future: COVID-19 policy responses and recovery, available at: https://www.oecd.org/coronavirus/policy-responses/rebuilding-tourismfor-the-future-covid-19-policy-responses-and-recovery-bced9859/, (26 March 2021)

18. Seraphin, H., Sheeran, P., Pilato, M. (2018). Over-tourism and the fall of Venice as a destination. Journal of Destination Marketing \& Management, Vol. 9, 374-376.

19. Škare, M., Soriano, D.R., Porada-Rochoń, M. (2021). Impact of COVID-19 on the travel and tourism industry. Technological Forecasting and Social Change, Vol. 163, 120469.

20. Skirbekk, V., Stonawski, M., Alfani, G. (2015). Consequences of a universal European demographic transition on regional and global population distributions. Technological Forecasting and Social Change, Vol. 98, 271-289.

21. Stojanovska-Stefanova, A., Atanasoski, D. (2017). UN goal: Sustainable Tourism as a key contributor for sustainable development in developing countries. First International Scientific Conference Challenges of tourism and business logistics in the 21st century »ISCTBL 2017《. Gevgelija/Shtip, 1, 152-161.

22. Stojanovska-Stefanova, A., Dimitrov, V.N., Magdinceva-Sopova, M. (2019). The significant role of the tourism in achieving the United Nations sustainable development goals. International Journal Knowledge, Vol. 34, No. 5, 1259-1264. 
23. Strielkowski, W. (2020). International Tourism and COVID-19: Recovery Strategies for Tourism Organisations. Preprints 2020.

24. United Nations-UN, (2020), Policy Brief, COVID-19 and Transforming Tourism, available at https://www.un.org/sites/un2.un.org/files/ sg_policy_brief_covid-19_tourism_august_2020.pdf, (25 February 2021).

25. United Nations - United Nations, (2020a), "On International Day, UN chief spotlights indigenous peoples' resilience in face of COVID-19 pandemic", 9 August 2020, available at https://news.un.org/en/story/ 2020/08/1069822, (23 February 2021).

26. United Nations - United Nations, (2020b), United Nations helps travel industry reopen safely and responsibly", available at https://www.un.org/ en/coronavirus/united-nations-helps-travel-industry-reopen-safely-andresponsibly, (08 March 2021).

27. United Nations Conference on Trade and Development - UNCATD, (2020), "Impact of the COVID-19 pandemic on trade and development: transitioning to a new normal", available at https://unctad.org/webflyer/ impact-covid-19-pandemic-trade-and-development-transitioning-newnormal, (23 February 2021).

28. Wen, J., Wang, W., Kozak, M., Liu, X., Hou, H. (2020). Many brains are better than one: The importance of interdisciplinary studies on COVID19 in and beyond tourism. Tourism Recreation Research, 1-4

29. World Tourism Organization - UNWTO, (2020), How are countries supporting tourism recovery?, available at https://webunwto.s3.eu-west1.amazonaws.com/s3fs-public/2020-06/BFN_V4.pdf (08 March 2021).

30. World Tourism Organization - UNWTO, (2020a), World Tourism Barometer, vol. 18, No. 2, May 2020, Madrid, available at https://doi.org/ 10.18111/wtobarometereng, (08 March 2021).

31. World Tourism Organization - UNWTO, (2020b), "Tourism in SIDS: the challenge of sustaining livelihoods in times of COVID-19", available at https://www.e-unwto.org/doi/epdf/10.18111/9789284421916, (08 March 2021). 
32. World Tourism Organization - UNWTO, (2020c), UN Secretary General: "It is imperative that we rebuild the tourism sector in a safe, equitable, and climate friendly manner", available at https://www.unwto.org/news/un-secretary-general-it-is-imperative-thatwe-rebuild-the-tourism-sector, (03 March 2021)

33. World Tourism Organization - UNWTO, (2020d), "Policy Brief: Covid-19 and Transforming Tourism", available at https://webunwto.s3.eu-west-1.amazonaws.com/s3fs-public/2020-08/SGPolicy-Brief-on-COVID-and-Tourism.pdf, (03 March 2021)

34. Yeh, S.S. (2020). Tourism recovery strategy against COVID-19 pandemic. Tourism Recreation Research.

35. Zhang, H., Cho, T., Wang, H. (2020). The impact of a terminal high altitude area defense incident on tourism risk perception and attitude change of Chinese tourists traveling to South Korea. Sustainability, Vol. 12, No. 1, 1-13. 